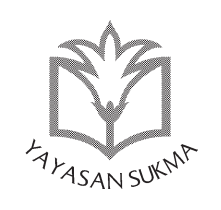

SUKMA: JURNAL PENDIDIKAN

ISSN: 2548-5105 (p), 9590 (e)

Volume 1 Issue 2, Jul-Dec 2017, hlm. 249-280

https://jurnalsukma.org/index.php/sukma/article/view/01202

\title{
ADOLESCENTS' IDENTITY FORMATION AS LEARNERS IN SUKMA BANGSA SCHOOL PIDIE, ACEH, INDONESIA
}

\author{
Nurhayati; ; ${ }^{1,2}$ Ratna Sari Dewi; ; ${ }^{1,2}$ Eero Ropo; ${ }^{2}$ Pekka Räihä ${ }^{2}$ \\ ${ }^{1}$ Sukma Bangsa School Pidie, Aceh, Indonesia \\ ${ }^{2}$ School of Education, University of Tampere, Tampere, Finland \\ email: nurhayatim87@gmail.com
}

\section{Abstract}

This study aimed to explore how adolescents performed towards their identity as learners in Sukma Bangsa School Pidie (SBP) through a phenomenographic approach. More specifically, the research had purpose to understand the way adolescents construct their learning identity in a school environment. The findings suggested that there were variations in the way adolescents experienced their learning identity that might encourage them to achieve different degrees of motivation, self-perceptions (self-efficacy, self-concept, and 
Nurhayati et al.

self-esteem), autonomy, and self-development towards their identity as learners. In this study, students exhibited a high level of self-efficacy and self-development, an average level of self-esteem and autonomy, and close to an average level of self-concept and motivation in constructing their identity as learners. The students also revealed that the highest accomplishment of their experiences was in showing their confidence towards learning attitude, whereas the lowest one was in adult attachment. Adult attachment therefore is pivotal to moderate students who have either low willingness to study or low self-conception.

[Penelitian ini bertujuan untuk mengeksplorasi pembentukan identitas remaja sebagai peserta didik di Sekolah Sukma Bangsa Pidie (SBP) melalui pendekatan fenomenografi. Lebih khusus lagi, penelitian ini bertujuan untuk memahami bagaimana remaja membangun identitas pembelajaran mereka di lingkungan sekolah. Temuan menunjukkan adanya variasi cara remaja membentuk identitas mereka, yang mendorong mereka mencapai tingkat motivasi, persepsi diri (self-efficacy, self-concept, dan self esteem), otonomi, dan pengembangan diri yang berbeda. Dalam penelitian ini, siswa menunjukkan tingkat self-efficacy dan self-development yang tinggi, tingkat self-esteem dan otonomi yang rata-rata serta konsep diri dan motivasi mendekati tingkat rata-rata. Pengalaman siswa yang paling tinggi menunjukkan kepercayaan diri terhadap sikap belajar, sedangkan yang terendah menunjukkan keterikatan pada orang dewasa. Oleh karena itu, keterikatan pada orang dewasa sangat penting bagi siswa yang memiliki kesediaan untuk belajar atau konsepsi diri rendah.]

Keywords: adolescent, identity, phenomenographic, learning identity, adult attachment 


\section{Introduction}

This study focused on students' academic attitudes in Sukma Bangsa Pidie (SBP) School. According to the researchers' rough observation within the last ten years in three Sukma Bangsa Schools (Pidie, Bireuen, and Lhokseumawe), students at secondary school level (high school) typically showed various learning attitudes depending on their interests. Additionally, most of teachers assumed that students who have the desired and good willingness to study expressed themselves by paying good attention to teachers and lessons during learning/teaching activities. However, this sign is not sufficient for teachers to ensure students' enthusiasm or eagerness in learning, hence, teachers must have capacity to understand comprehensively their students both in emic and in etic perspectives.

Students who are ranging from grade 7 to 12 are basically refer to adolescents. In this period, they overcome identity versus identity diffusion (role confusion) concerning their development tasks as mentioned by Erikson (1968). As a consequence, adolescents (secondary school students) attempt to find whom they are and what kinds of roles they will take as learners. Moreover, they have a tendency to lose study motivation, to be truant, to avoid their responsibility, and to violate schools' regulation. Adolescents' behavior changes are indicated by having no purpose going to school, or they just want to meet their friends for playing, or they even attempt to fulfill their parents' expectations.

In line with these phenomena, the study relating to adolescents' experiences towards their learner identity formation is critical to be conducted. As we observed during gathering the data in this research, the students in SBP School did not have their learner autonomy, and they also could not exhibit their identity as agents of change as learners. Additionally, it is supported by two well-known theories concerning adolescents' identity formation as proposed by Erikson (1968) and Marcia (1966) about psychosocial development, and identity status. The other research from (Côte and Levine 1988; Berzonsky 1990) also suggest that indi- 
vidual's self-concept and beliefs on how she or he perceives her or himself are established by individual's identity. In addition to this, adolescent's identity formation process was affected by individual's exploration and commitment as mentioned by Duriez, et al. (2012).

According to Havighurst in a book written by Kelly (1965), identity formation of adolescents must be consulted to their developmental tasks, for instance, personal achievement. In this period, they have a tendency to establish self-confident, gain an understanding of their environment, develop their independency, know their roles in society, and they also must be able to decide their life direction. Hence, teachers must take their roles to concern about these issues in the school environment. Teachers are expected to help their students in constructing their identity, because in adolescence period, they are in the middle of experimenting whether they succeed to find and form their own identity or not. Therefore, the authors believe that the positive support from parents, peers, teachers, and others will influence the adolescents on their life experimentation.

In this study, we attempted to understand an identity formation process of students as learners in SBP School, in order to afford sufficient background knowledge and in-depth descriptions about adolescents' attitudes as learners to readers or educational stakeholders. Sukma Bangsa Schools have orientation in children's development and quality. These schools were built in response to the reverberation of huge earthquake followed by Tsunami that hit Aceh and North Sumatera at the end of 2004. According to Blueprint of Sukma Bangsa School (2005), the schools basically were designed to reach underprivileged Aceh children for their better education and to educate them with nation character building.

There are three schools in different locations of Aceh region as previously mentioned in the beginning, one of them is Sukma Bangsa Pidie (SBP) School, which still has both boarding and nonboarding programs. This research therefore was conducted from 
10 August 2016 to 11 October 2016 in SBP School. Even though this school was established about 10 years ago, but neither the experienced nor the novice teachers who are working there have ever performed as researchers. For that purpose, this preliminary study will become more important for future school assessment and development. Thus, the purpose of this research is to understand how adolescents behave toward their identity as learners in SBP School through a phenomenographic approach in order to explore the ways of they construct their identity as learners in such a school environment.

As Erikson (1968) previously stated that central adolescents' developmental tasks related to their identity formation in terms of the way they attempt to create the sense of identity. One's self-concept and self-esteem can be established through one's sense of identity. Moreover, several researchers agree that selfconcept is not formed straightaway prior to having self-efficacy (Bong and Skaalvik 2003; Schunk 1991). Learners who are able to encourage the development of self-concept in the proper way have capability to construct their self-efficacy towards academic performance continuously. Also, according to Whannell and Whannell (2015), students' identity formation during their transition of late adolescence may be influenced by their emotional commitment. They are expected to perform well as learners when they can act and maintain their emotion properly.

Furthermore, some of self-esteem characteristics of individuals as learners are learners' attitude and motivation, including their self-acceptance without paying attention to what other people think. In addition to this, according to Bandura (1977), social learning theory defined self-efficacy as an effort, an intended to face obstacles, an anxiety, and a defensive behavior. And one of key factors to attain learners' self-efficacy is motivation (Ryan and Deci 2000). Basically, highly self-efficacious learners are indicated by persisting longer, working harder, and participating more readily in studying than low self-efficacious ones (Zimmerman 2000). Learners' self-efficacy, motivation, and identity therefore inform the complexity in order to understand 
Nurhayati et al.

adolescents' psychological development (Matthews, Banerjee and Lauermann 2014).

Concerning students' identity formation, we proposed three aspects of learners' perceptions; more specifically, self-efficacy, self-concept, and self-esteem. And adults are expected to aid and guide adolescents in order to explore their academic identity as responsible learners by employing their own autonomy. Hence, self-directed learning, self-assessment and evaluation are important to be discussed regarding learners' autonomy in studying. An autonomous learner is able to understand instructional processes, and she/he also can encourage self-directed learning by using her/his autonomy (Harrison 1978; Brockett and Hiemstra 1991).

In line with this, according to Garrison's model, a highlymotivated learner has a tendency to control and monitor her/ himself as individual to gain the learning outcomes (Song and Hill 2007). Additionally, self-assessment also has strong correlation to learners' autonomy, since it may reassure them to be more responsible and independent for their own academic process. The autonomy of learners then can be concluded as freedom for learners to select their own learning approaches, and to be dependent on, and responsible for their own interests with some criteria, for example, the ability to assess, evaluate, manage, regulate, self-direct, and self-aware their own learning, intrinsically motivated, pro-active, constructive criticism, and also having the right to manage their own learning direction (Benson and Voller 1997). Given these points, learner identity in adolescence in general concepts covers student's perceptions (self-efficacy, self-concept, self-esteem), self-development, motivation, and autonomy that includes self-directed learning, self-assessment and evaluation.

In a nutshell, this study basically will provide the different perspectives of the ways of adolescents construct their identity as learners in SBP School. The discussion will contain descriptive categories that determine several key points of the essence 
of this phenomenon in selected study area, since we assumed that learner identity is constructed from adolescents' motivation and self-perceptions. Further, several main experiences observed from student participants as indicators for the researchers to assess learner identity formation will be discussed as well in the next section.

\section{Research Methodology}

The data gathered for this study were obtained from observations, including classroom observation, peer-observation, and self-report. Additionally, focus group discussion was also done to understand group dynamics of participants instead of personal interviews. To get data triangulation in order to support main participants' (students') interviews, this study also interviewed their base class teacher, subject teachers, dormitory teacher, vice principal of student affairs, school principal, and some representative parents. The purpose of teachers' interviews was to confirm the data that we obtained from student participants. The information about students' conditions from the teachers was also used to select the other prospective participants associating with the recommended snowballing approach. We used the students' interviews for our primary data, meanwhile the other supported interviews as our secondary data, to ensure informants' information that we obtained previously. Likewise, the other methods that we employed together with interviews (i.e. classroom observation, peer-observation, self-report, and focus group discussion) were occupied systematically to interpret our findings accordingly.

In addition to this, the participants in this study were students of SBP School at $11^{\text {th }}$ grade of senior high school level, teachers, and parents. People having similar or distinct characteristics, attitudes, and experiences associated with inquiry phenomena can be selected as target audiences (Bonde, 2013). Data collection therefore was obtained from students with several designated criteria. The criteria of the participants were 
Nurhayati et al.

as follows:

The first batch of students who are currently studying at senior high school level. They have joined the SBP School since elementary school and continued their studies until now as boarding students.

The non-boarding and boarding school students who just joined the school in recent years.

The students who were proposed and recommended by their teachers or school principal (informants' snowballing).

Moreover, the overall research was conducted from 10 August 2016 to 11 October 2016 in Sukma Bangsa Pidie (SBP) School. We first did classroom observation confidentially prior to interviewing the participants in order to acquire the factual data from them. Actually, the same shortlisted student participants were followed up all the time starting from observations until the last stage of data gathering in this research. Afterwards, we asked their peers to do a secret observation within 2-3 days for each participant, and after this, the participants were interviewed personally and let them write some reports about themselves as learners (self-report). At the same time, we did interviews with their teachers and parents simultaneously and conducted focus group discussion by the end of interview sessions. All students (35 people) were involved in FGD, however, we observed only 15 student participants in our research. We therefore separated those 15 participants into four groups together with the rest students in that class.

In this study, the interviews were used as primary data, whereas the observations would support this study as secondary data to ensure the validity and reliability of the data gathered. All interview sessions were recorded and transcribed into written transcripts (verbatim). In addition, participants were given the opportunity to review the transcripts of their interview results, yet they did not use this chance accordingly. Instead of these two methods, according to Larsson \& Holmstrom (2007), data col- 
lection for this research approach could be simply gathered by using open-ended interviews to encourage participants provide superficial information about their experiences with tangible descriptions and examples.

Concerning ethics statement for this research, the approval to conduct this study included informed consent procedures obtained from Ethics Approval Committee of School Education, University of Tampere. Prior to examining the study, this ethics approval was offered to shortlist informants who voluntary participate and they were informed that they are able to withdraw their given information from this research at any time. The signed consent form was returned to researchers, and we must assure participants' confidentiality. Moreover, the interview topic guide was also shared to participants prior to conducting a semi-structured interview.

\section{Descriptive Categories}

Concerning adolescents' identity formation as learners, we assumed that it is influenced by some aspects of self-perceptions, learner motivation, and autonomy. At a certain point, adolescents experience such different ways over the time, which are also affected by their surroundings instead of individuals themselves. More specifically, we proposed learner identity as follows; self-efficacy, self-concept, self-esteem, self-development, motivation, and autonomy. These six indicators later may help researchers to understand how the different ways of learners explore their identity regarding their learning process. As cited in Falsafi $(2010,94)$, learner identity was defined as "the individual's sense of recognition as a learner based on the constantly re-constructed meanings about herself as a learner with a higher or lower level of disposition and capacity to learn in different kinds of contexts and situations". Hence, when a person is able to reconstruct meanings about her/himself as a learner in different contexts and environments, she/he already has learner identity.

Some of key concepts relating to learner identity used in this 
Nurhayati et al.

research were explained by Bandura (1977), Baumeister (1999), Fredricks, et al. (2004), Maehr and Meyer (2004), Reeve (2006), and Holec (1979). Self-efficacy is defined for learners who are able to perceive their effort, intended to face obstacles, anxiety, and defensive behavior. In addition, when learners can build or at least to recognize their own belief about themselves including personal attributes, who, and what the self is (learners' ideas about themselves) is called by self-concept. Self-esteem refers to learners who understand the way they evaluate themselves, and at this point, learners are expected to present broadest self-evaluation. Alternatively, self-development is understood as learners who are able to develop and be responsible for both their own and other people learning (agency) with taking account on assessment process as well as reflection. Meanwhile, learners who have motivation indicate a state that energizes, directs, and sustains behavior. And autonomy is defined for learners who are independent in deciding their own learning instead of to be dependent on the teachers or parents.

\section{Learner Identity Formation}

Several main experiences noticed from student participants are their willingness to study, their emotional experiences, their confidence, their cognitive ability, and adult (parents and teachers) attachment. These five aspects will be indicators for researchers to assess each item of learner identity concerning the different ways adolescents experienced it. Since in this period, adolescents are tremendously overcoming complicated problems due to their identity confusion.

\section{Self-efficacy}

After conducting several interviews with 15 student participants ( 7 males and 8 females), regarding their willingness to study, most of students had high self-efficacy. They exhibited their good efforts to study, for instance, they demonstrated hard work, had sense of accomplishment, and were confident with their own 
abilities. We notice that students' perceptions about themselves could be observed from their direct speech and acts. Self-efficacy basically refers to students' perceptions. Ryan and Deci (2000) emphasized motivation and self-efficacy are intertwined based on the theory of self-determination. In this theory, they claimed that motivation contributed to achieve learners' self-efficacy.

On the contrary, low self-efficacious students exhibited lower motivation to study, for example, a student studied when the book was provided by the school only. The worse one was admitted by another student, she did not really persist to study when she could not deal anymore with the tasks given, and she easily gave up by expecting her friends' works that have already done. We accept that her case was normally happening especially for students in adolescence period, in case of they still need others to assist either from peers or from adults. To put it briefly, self-efficacy may not be assessed only by students' willingness to study, but also from the ways they perceive and predict their ability (level of confidence).

With this in mind, the previous study from Zimmerman (2000) also stressed that learners with high self-efficacy are able to persist learning longer than the low ones, they have no doubt of their capabilities by showing their confidence in learning activities as well. Notwithstanding highly self-efficacious students were dominant in this school in terms of their confidence of the ability, some students (but not many) were still in the average level of self-efficacy, we can say it "fair" for such a school community.

What we noticed here is the students actually already became proficient at some lessons or were able to solve the problems given by the teachers, but in fact, they still feel less confident with their own capability, and need other people supports. We understood that this is not typically happened without any reasons, for instance, one of them exhibited her anxiety to be in front of class or other people. We then coincide to involve adolescents' emotional learning experiences in order to assess 
Nurhayati et al.

self-efficacy accurately.

The relationship between students and teachers (sometimes students' parents) is considered having association with students' emotional learning experiences. Previous study confirmed that emotions have a tendency to enhance the ways people think and self-regulate their learning that later lead academic attitude effectively (Mayer and Salovey 1997; and Salovey and Mayer 1990; as cited in Rivers and Brackett 2008).

Another study from Elias et al. (1997) as cited in Rivers and Brackett $(2008,4)$ described the social and emotional learning (SEL) as "the process of integrating thinking, and behaving in order to become aware of the self and of others, make responsible decisions, and manage one's own behaviors and those of others". This definition demonstrates the important role of SEL in students' academic attitude. This term has the exceptional position (an independent aspect) from the previous adolescents' experiences (willingness to study and level of confidence) in constructing their identity as learners. In line with this, we suppose that adults' attachment is needed in order to maintain and guide them to the best-suited directions or goals.

The findings from this study presented that students with high and fair self-efficacy dealt with various emotional experiences toward their learning approach. Some students demonstrated that emotional situation (i.e. mood) influenced students' self-efficacy. Dealing with this problem, supports and motivation from other people is compulsory, they may be their friends, teachers, or even parents. To accommodate this issue, we then included adult attachment to aid adolescents in shaping their learner identity through emotional development, as we understood that adolescents-adults' relationships later may affect their selfconcept as well as self-esteem. Not only did student participants express whether they have good perceptions about teachers and parents' involvement, but also adults sometimes were not much value for their learning process.

In order to complete these study findings regarding the dif- 
ferent ways adolescents experienced their position as learners, we added another indicator, so-called cognitive ability. Students' cognitive suited an independent aspect in constructing their learner identity. We indicated that every student has different level of learning engagement capability, so that teachers are not expected to judge whether some students are smart and the rest is not. It encourages shaping fixed learning identity as discussed by Kolb and Kolb (2009). Their study about the concept of learning identity suggested that it was prohibited for a teacher to go straightforward on students' ability evaluation without any preliminary helps and supports from him/her regarding their learning problems. Because students who perceive themselves as the incapable ones will not be aware of themselves as learners at all in case of having "fixed" views about themselves and this problem further decreases their self-efficacy accordingly.

Moreover, some of students ever had trouble in study, however they seemed to want to improve their ability for good with showing high self-efficacy though they detected that the existing performances or abilities were not sufficient yet. More specifically, the second student also expressed his efforts to deal with his difficulties when he felt down and wanted to give up. In this case, internal and external motivations are considered as the most important factor in order to maintain their willingness to study and later to encourage positive perceptions about self-efficacy. Although cognitive ability stands as an independent aspect, we presumed that the other experience indicators (willingness to study, emotions, level of confidence, and adult attachment) would influence in improving students' cognitive performances accordingly.

\section{Self-concept}

As cited in Schunk (1991, 207), self-concept and self-efficacy differentiate in terms of specific assessment of the context in performing a particular task, whereby self-concept may be concretely defined as "an individual's judgment of his or her 
Nurhayati et al.

capabilities to perform given actions". Pajares (1996) also emphasized that self-concept refers to the assessment of broader context rather than specific task as represented by self-efficacy.

Regarding adolescents' willingness to study, the findings exhibited that there were various levels of self-concept obtained in the way students judged and expressed themselves toward learning approaches. The range of variation of experiences covered low, fair, and high self-concepts. A student's experience demonstrated that he had a bad existing concept about himself whether he would not be able to deal with his difficulties in learning when teachers asked him to do some particular assignments without getting helps from his friends. This perception encouraged him to be unintended to review the lessons, as well as not to give his efforts accordingly; consequently, his willingness to study was affected by his previous self-concept. Fortunately, he realized that he was actually able to reinforce himself in learning activities by expecting aids from his friends.

On the other hand, another student showed a fair selfconcept in terms of his willingness to study. He did not want to force himself to study hard and he emphasized that to be a stupid student is not his expectation as well. Dealing with this issue, we intended that he is kind of an "easy going" student. In case of he was able to accomplish the designated goals and achievements, which is more than enough for him. Moreover, the other student also exhibited a very positive self-concept about herself. What we noted here is she was not good at English in the previous time, but she recently demonstrated her proficiency at English speaking due to her high self-concept. She believed that she is now able to prove her good performance in English, and then she happily chose to be a leader in language department of the school without any hesitattion.

In forming learner identity, one's self-concept gives a pivotal role to students' learning performance in case of the perception of themselves affects their learning. The previous research showed that there was a significant association of self-concept 
with academic performance persistently, and a high self-concept encourages students to have good feelings about their abilities and competencies to enhance successful achievement (Khor n.d.).

By the same token, emotional experiences of adolescents in shaping their self-concept will be discussed as well. What we found here is in their adolescence period, the emotions contributed much more than the other experiences to their self-concept formation towards learning attitude. In self-concept formation, when individuals have negative perceptions about themselves, then their emotional well-being will contribute to academic success (Wright 2011).

In addition, to moderate this issue, peers, teachers, and parents play very important roles, as we understood that selfconcept was shaped and created by one's experiences integrated with the environment (Shavelson, et al. 1976 as cited in Wright 2011). The positive integration from environment may help adolescents to maintain their emotions and acts in an appropriate way instead of the ignorance from others. Actually, we also concord that the teacher is expected to understand what every student needs towards their learning problems particularly in the school context. According to Harter (1999) as cited in Manning (2007),

As students transition from middle level to high school, their self-concept gradually grows, and as a result increasing freedom allows adolescents greater opportunities to participate in activities in which they are competent, and increased perspective-taking abilities enable them to garner more support from others by having more socially acceptable ways (p. 11).

We therefore suggest that both teachers and schools must be able to accommodate, accept, support, and aid students as they are appropriately by enhancing their freedoms and opportunities in deciding their learning approach.

As a matter of fact, level of confidence of adolescents about themselves also affects their self-concepts accordingly. Adoles- 
Nurhayati et al.

cents in presenting their confidence level are also influenced by the presented environment, then they unconsciously attempt to compare themselves with other people. When they find their positions, the level of confidence consequently increases.

In terms of students' cognitive ability, as consulted from the previous research (Sanchez and Roda 2003), it illustrated that there is relationship between self-concept and academic performance. The research also highlighted whether it is necessary for schoolteachers to provide their sufficient attention through educational processes to guide students in constructing positive self-concept. The results showed that the academic achievement degree is related by one's self-concept level (Sanchez and Roda 2003). The following excerpt from student's experience exemplifies the self-concept towards her cognitive ability.

But if there are a lot questions given, then I cannot solve it, for example chemistry subject, it's very hard (S10 Interview, 06 October 2016).

It displays her perception whether she was not able to solve chemistry problems, as indicated by "very hard". Students who have this kind of negative self-concept, even though the tasks given are not "very hard" for them, they already have in their mind whether such a particular subject seems not easy to deal with, then it may decrease their willingness to study. These students also mentioned that in case of there were many questions offered by the teacher, she immediately felt that she could not solve it without giving her best effort in advance, this student positioned herself as an ego involved learner as proposed by Yahaya (2004).

For some students who have good perceptions about their cognitive ability, they even do not really consider about the amount of problems offered to be solved, in this case they have orientation in task involved learners (Yahaya 2004). They also do not care about other judgments due to their cognitive achievements; the focus is solely on mastering and solving the tasks. Assistance from others may help the first of learners (ego-involved learners). From our perspectives, adult attachment, especially teachers, 
plays a pivotal role to encounter such problems.

\section{Self-esteem}

Self-esteem is the way individuals respect themselves and later they may be able to value how confidence they are in doing something related to a certain ability. As described by Slavin (2005), adolescents with positive acceptance by adults will get a high level of improving their self-esteem. Moreover, Maertz (n.d.) and Manning (2007) mentioned that positive behavior will appear in adolescence depends on how they and adults perceive self-esteem, such as in terms of emotional controls. When they can manage their emotions, it will affect their motivation and may enhance their efforts to study.

Willingness to learn usually will increase when adolescents have high motivation to know about something, such as their curiosity for new knowledge. They usually attempt to do new things or confirm something that they are curious about it. In this period, teenagers with positive self-esteem usually do not want to give up until they can achieve their purposes or goals. From interviews, we found some students in this school expressed good willingness to study, for example,

Sacrifice everything, ups and downs [towards studying attitude] (S8 Interview, 06 October 2016).

These students showed that she loved to study and would keep trying although she faced learning difficulties. Here, this learner also expressed that she had good supports from the others. In fact, the student acted positively in the school and at home, as mentioned by her parents and teachers. Even though her academic was not satisfying yet, she already showed good performances towards academic and social life. In his book, Slavin (2005) explained that students would react positively for having good support which they might get from others, in order to perform positive behavior related to their study, interactions, and emotions. 
Nurhayati et al.

Further, as mentioned by Lavoie (2008) and Manning (2007), children who are taught by good acceptances and respects will be able to develop their positive self-esteem. Immediately, when he or she becomes a learner, the student will perform a high level of willingness to study. In particular, the student in this case tends to perform a good attitude either in the school or at home. Based on our observations and experiences, she already had a strong eagerness to study during staying in dormitory. She had never been reluctant to ask something that she did not know yet. It could be because she usually did in the previous study time. She would ask teacher courageously, as mentioned by her parent, it also happened when she was in elementary and junior school.

On the other hand, the other student with lower self-esteem demonstrated her willingness to study also at lower level. She did not show a good learning attitude rather than only to pass the minimum requirement of learning goals. Formation of self-esteem in adolescence is closely associated with emotional experiences that they received from environment. As mentioned by Manning (2007), the treatment, which was received during childhood, will remain long lasting in the formation of self-esteem. Therefore, if a child has a good acceptance from their surroundings, then emotion establishment becomes steadier. It affects behavior of adolescents, such as social interactions, academics, characteristics, and emotions.

Based on the interviews, we could analyze that he felt not confident in the beginning. However, he became more confident now; he even had another responsibility for the school to be a peer-teacher for his juniors in the dormitory. He acquired a good acceptance from adults as well as friends. In line with this case, as stated by Slavin (2005), people who can gain much improvement in dealing with their emotional experiences, will consequently be able to adjust their self-esteem formation accordingly.

The other experience of learners in improving self-esteem is level of confidence. Again, adolescents will demonstrate a high level of confidence if they are highly motivated. Regarding 
self-esteem aspect, learners will achieve good motivation if they get positive acceptance by their environment, particularly from adults. They will not be hesitated to determine their own dreams for the best future due to their capacity to value themselves as good learners. Students with positive self-esteem will have good motivation to study and consequently give impact to their cognitive ability, they then can attain good academic achievements. As offered by Ferkany (2008), scholars with high self-esteem have a tendency to demonstrate good behaviors.

As we previously enlightened, adult attachment is one of the important factors in the purpose of enhancing one's selfesteem, because adolescents cannot be separated from adult involvement in the period of shaping their self-esteem (Slavin 2005). To be concluded, teachers and parents' scaffolding on adolescents' self-esteem construction becomes more essential. Adult encouragement affects the formation of adolescents' self-esteem. At school, teachers become role models for students in the way they provide and conduct learning approaches. The sample above explained how mother's involvement (adult attachment, in general) was very important for the student's development tasks. As we observed, she exhibited low level of willingness to study due to her personal problems that might come from (one of them) parents, or the other factors from her surroundings. She actually needed special treatments from adults, and it can be clearly noticed because she complained about the teacher approaches in presenting lesson and learning materials.

\section{Self-development}

Self-development has a strong correlation with intrinsic motivation in terms of individual improvement regarding his or her capacity (Schwartz et al. 2013; and Department of Education and Early Childhood Development 2007). In this case, adolescents attempt to improve their ability in academic and social skill. Learners who have good motivation will realize that they have to take account of their better life in the future. By learning new 
Nurhayati et al.

things, they have a tendency to create the particular purposes for themselves, such as to be better in either social or academic aspect. Consequently, they will be independent and autonomous learners. Teenagers with a high level of autonomy have a strong desire to develop their talents related to their needs. They usually are able to assess their own capacities as students.

Emotional experiences among students will affect the improvement of both their self-esteem and self-development. When they show their eagerness to do something, it later promotes them to start controlling their emotions, and ultimately gives impacts on their academic and social skills improvement.

Alternatively, we also have those kinds of experiences with many students in this school. It happened not only during this research, but also we found similar students' attitudes from the first year of this school established. There were fair in academic achievement but had very good improvement in their emotional experiences. It also demonstrated that adolescents needed to be assisted by adults emotionally; therefore, they later will improve their self-esteem. Hence, they then can control their emotions properly.

As argued by Brown and Marshall (2001), adolescents with good behavior will have position in positive dimensions of emotional experiences. They want to explore more on how to become more confident rather than disgrace (in negative side). The level of adolescents' confidence will associate with their actions accordingly. Again, positive attitudes from learners become a good part of improving their capability.

Manning (2007) proposed that learners tend to increase their ability when they make interactions with others, in which the environment can recognize efforts of their competencies in both academic and social factors. The student in this excerpt illustrated that she felt very confident in case of her friends asking her to be their leader in peer teaching. Not only that, this action also could help her to understand new knowledge that she got from the learning-teaching activities. It was confirmed by her 
explanation that she was able to learn and become more understand after she taught her friends. Moreover, she would get challenges to find other resources for study.

Based on our experiences in this school, peer teaching has capacity to help our students in enhancing their level of confidence related to their competencies. In a group study, they have additional responsibility to teach their friends according to their ability. From our experiences in this school, most teachers will assist students in appropriate ways, either in the dormitory or in the school. Students must acquire equal treatments from teachers. Likewise, what astonish us is these students felt that their presence is very meaningful. It is due to good environments that they experienced, and they received the treatments proportionately.

As noted by Reeve and Jang (2006), to help students improve their abilities, teachers must create a conducive environment, including proper assistances, encouragements, and supervision. The best reinforcement to construct students' behavior is a support from adults regarding their autonomy as learners. Adolescents will feel appreciated when adults provide good scaffoldings for them. On the other hand, negative behavior of teenagers will then appear when adults try to assist them by inappropriate attachment.

\section{Learner Motivation}

As we previously discussed, adolescents with high self-esteem as learners, have integrated correlation with their attitudes and motivation by showing their self-acceptance without having doubt with their own ability. Besides, according to Ryan and Deci (2000), motivation is one of the pivotal factors to achieve learners' self-efficacy, in which we can understand that adolescents with no motivation to study do not have intention or close attention to learning activities and later lead them to having low self-efficacy. For this reason, learner's motivation and identity inform the complexity in order to understand adolescents' psy- 
Nurhayati et al.

chological development (Matthews, Banerjee, and Lauermann 2014). In addition, according to Garrison's model as cited in Song and Hill (2007), they also illustrated those learners who have a strong motivation to learn, they have a tendency to control and monitor themselves as individuals in order to attain their learning outcomes.

This phenomena was supported by Ormrod (2008, 384-386) who mentioned that every student may have different motives in learning, for instance, "one student may be keenly interested in classroom subject matter and seek out challenging course work, participate actively in class discussions, and earn high marks on assigned projects", conversely, "another student may be more concerned with the social side of school, interacting with classmates frequently, attending extracurricular activities almost every day, and perhaps running for a student government office". Furthermore, the rest may focus on such athletics and sports activities, parents' needs, or even unknown motivation. As exhibited by the second excerpt, another adolescent's motivation to study was due to her parents' concerns. This case then will have association with learner awareness level, which will present in the next discussion of this thesis. Additionally, motivation is also related to students' emotions. Dealing with their emotional experiences, most students involve their feelings prior to being motivated to study.

Cognitive ability becomes another problem to deal with students' motivation. Although cognitive ability is such an independent aspect in forming learner identity, it plays indirect influences toward the motives of student to study. Motivation is assumed to be able to enhance learning performances (Ormrod 2008). In case of students do not have high motivation to perform their learning anymore, then as a result, their accomplishments will decrease as well, it is depicted in the second student's experience. The triangulation data that we obtained exhibited that this student ever performed in chemistry subject very well during his previous time due to highly motivated by the teacher. However, he had difficulties in learning recently because he could not get an 
appropriate encouragement from the subject teacher anymore.

The findings above is associated with adult attachment as well, in this case is teachers. Besides, parents also become motivators for adolescents towards their learning activities and goals.

\section{Learner Autonomy}

We advise that learner autonomy is related to at least these three aspects; self-directed learning, self-assessment, and selfevaluation. Self-directed learning (SDL) involves autonomy of learners to understand the instructional processes whereby it focuses on two orientations, a process, and a goal (Brockett and Hiemstra 1991).

Additionally, self-assessment is also directly related to learners' autonomy because it may encourage them to be responsible for and independent to their own learning progress. When a student has a good self-assessment, he or she will be a processoriented person rather than result-oriented person, in case of he or she is able to focus on learning process. Generally speaking, "the autonomous learner takes a (pro-) active role in the learning process, generating ideas and availing himself of learning opportunities, rather than simply reacting to various stimuli of the teacher" (Boud 1988; Kohonen 1992; and Knowles 1975 as cited in Thanasoulas 2000).

To demonstrate adolescents' experiences regarding their autonomy in learning activities, we then discuss learner autonomy in terms of their willingness to study as exhibited in the following two excerpts.

Listen, then write a little, there are special codes [that I myself create]... (S1 Interview, 06 October 2016).

[Who asks you to study?] yes, my own decision (S5 Interview, 14 August 2016).

Based on S1 interview's excerpt, he admitted that he created any particular codes to mark his notes about the lessons. He listened to the teacher, and wrote the notes as he wanted, as 
Nurhayati et al.

long as he could understand and was able to get the meanings of the notes that he already wrote. Furthermore, the second excerpt showed the student's claim about her decision to study without any other influences or pressures. From these two examples, we could point out that these two students already had their own freedom to decide the learning approaches; both of them are autonomous learners. They studied because their intrinsic motivation with their own ways. According to Omaggio (1978) as cited in Thanasoulas (2000), he clearly stated that "autonomous learners have insights into their learning styles and strategies, and take an active approach to the learning task at hand", these learner's characteristic indicate that the last two experiences of the students confirmed what Omaggio advised previously.

Emotional experiences will also contribute to adolescents' autonomy towards their learning attitudes. Sometimes, they do not want to select some activities because it may affect their emotions and later will encourage negative perceptions about themselves as good learners. Generally, students with good autonomy will have a high level of confidence. Many students seemed like to complain their scores, but not many of them could stand with good reasons. By way of contrast, the students' experiences above demonstrated that they were very sure about their answers whether it was corrected that the teacher mistakenly scored it. In addition, the second excerpt illustrated the student with highly confidence on his ability on science subject, and later encouraged him to decide science for his particular interests.

What is more, we also think that autonomous students will have good cognitive capabilities accordingly, because to get engage with a certain learning environment is easy for them due to their independency. It was reinforced by Benson and Voller (1997) study, they projected that an autonomous learner has several particular characteristics, for instance, they are able to assess, evaluate, manage, regulate, self-direct, and self-aware their own learning, intrinsically motivated, pro-active, constructive criticism, and further having the right and ability to govern their own learning direction. 


\begin{tabular}{lllllll}
\hline \hline $\begin{array}{l}\text { Experi- } \\
\text { ence }\end{array}$ & $\begin{array}{l}\text { Self-ef- } \\
\text { ficacy }\end{array}$ & $\begin{array}{l}\text { Self- } \\
\text { con- } \\
\text { cept }\end{array}$ & $\begin{array}{l}\text { Self- } \\
\text { esteem }\end{array}$ & $\begin{array}{l}\text { Self- } \\
\text { devel- } \\
\text { op- } \\
\text { ment }\end{array}$ & $\begin{array}{l}\text { Moti- } \\
\text { vation }\end{array}$ & $\begin{array}{l}\text { Auto- } \\
\text { nomy }\end{array}$ \\
\hline $\begin{array}{l}\text { Willing- } \\
\text { ness to } \\
\text { study }\end{array}$ & High & Fair & Fair & Fair & Fair & High \\
$\begin{array}{l}\text { Emo- } \\
\text { tional }\end{array}$ & Fair & Fair & Fair & High & Fair & Fair \\
$\begin{array}{l}\text { Showing } \\
\begin{array}{l}\text { Confi- } \\
\text { dence }\end{array}\end{array}$ & High & High & High & High & Fair & High \\
$\begin{array}{l}\text { Cognitive } \\
\text { ability }\end{array}$ & High & Low & Fair & High & High & Fair \\
$\begin{array}{l}\text { Adult at- } \\
\text { tachment }\end{array}$ & Low & Fair & Fair & Low & Low & Low \\
\hline
\end{tabular}

Figure 1: Adolescents' experiences in constructing their identities as learners

In summary, Figure $\mathbf{1}$ displays adolescents' experiences in constructing their identities as learners. From the six themes that were projected by the researchers, the overall students' experiences showed high levels of confidence, except in motivation. In contrast, adult attachment (to both teachers and parents) demonstrated a negative effect (low to fair) due to adult's inappropriate treatments and involvement with the students.

The findings confirmed that teachers sometimes could not guide and assist their students, as they needed, whereas parents intervened in the learning approach in an unnecessary way. Moreover, both parents and teachers sometimes attempted to compel their own expectations to the students and later might decrease the students' freedom in deciding their activities related to academic study. 
Nurhayati et al.

\begin{tabular}{|c|c|c|}
\hline $\begin{array}{l}\text { Catego- } \\
\text { ries }\end{array}$ & $\begin{array}{l}\text { Degree of } \\
\text { accomplish- } \\
\text { ment }\end{array}$ & Interview transcripts \\
\hline \multicolumn{3}{|c|}{ Learner identity } \\
\hline $\begin{array}{l}\text { Self-effi- } \\
\text { cacy }\end{array}$ & Fair to high & $\begin{array}{l}\text { "Every weekend I normally do inde- } \\
\text { pendent learning, such as looking for } \\
\text { additional knowledge from internet }(. . .) \text { " }\end{array}$ \\
\hline $\begin{array}{l}\text { Self-con- } \\
\text { cept }\end{array}$ & Fair & $\begin{array}{l}\text { "How to say... I'm a fussy person... eum, I } \\
\text { love to make a joke, but when I'm serious, } \\
\text { I don't like to be bothered by others." }\end{array}$ \\
\hline $\begin{array}{l}\text { Self-es- } \\
\text { teem }\end{array}$ & Fair to high & $\begin{array}{l}\text { "Ooo... I have average scores, and high } \\
\text { scores as well... most of my scores are } \\
\text { high." }\end{array}$ \\
\hline $\begin{array}{l}\text { Self- } \\
\text { develop- } \\
\text { ment }\end{array}$ & Fair to high & $\begin{array}{l}\text { "I like, for example, the teacher gives the } \\
\text { assignments, for those who can answer } \\
\text { then will get additional marks, and the } \\
\text { problems are harder... it becomes chal- } \\
\text { lenges for all of us, I love it." }\end{array}$ \\
\hline $\begin{array}{l}\text { Motiva- } \\
\text { tion }\end{array}$ & Fair & "Yes, study seriously, I love my parents." \\
\hline $\begin{array}{l}\text { Autono- } \\
\text { my }\end{array}$ & Fair to high & $\begin{array}{l}\text { "Complain about score? (...) aaa... math- } \\
\text { ematics, often, often I complain about } \\
\text { the score (...) because what I think it } \\
\text { was correct (...) was mistaken [by my } \\
\text { teacher]." }\end{array}$ \\
\hline
\end{tabular}

Figure 2: Highlighted interviews' transcripts concerning learner identity formation

We also assume that although some of adolescents already had their autonomy and were responsible for their own learning, parents often offered their own expectations to be considered by their children. Moreover, teachers also often decided their own learning approaches which might be not suitable for the students and attempted to make they could accept it naturally. However, in terms of adolescents' willingness to study, their emotional experiences, as well as cognitive ability, the results demonstrated a fair to high levels in the accomplishment of self-efficacy, self-concept, 
self-esteem, self-development, motivation, and autonomy. Figure 2 exhibits some highlighted interviews' transcripts concerning learner identity formation based on its degree of accomplishment.

\section{Concluding Remarks}

This research employed a phenomenographic approach in the interpretation of the results, hence, readers then may have their own conclusions to justify the outcome spaces of the study. We understand that there are various backgrounds of readers, influencing the way they interpret and determine the meanings of these findings, regarding their different points of view. Therefore, the conclusions provided correlate to the researchers' perspectives and are based on educational research interests. In brief, there are variations in the way adolescents experience their learning identity, and consequently they achieve different degrees of motivation, self-perceptions (includes self-efficacy, self-concept, and self-esteem), autonomy, and self-development towards their identity as learners. In this study, SBP School's students demonstrated a high level of self-efficacy and self-development, an average level of self-esteem and autonomy, and a close to average level of self-concept and motivation in constructing their identities as learners. The results also demonstrate that adult (in this case teachers and parents) involvement with adolescents' learning approaches may encourage the learners to become less or more autonomous people.

We therefore recommend future research to investigate the association of learner identity with academic attitudes, as well as learner identity with academic and social achievements, both qualitatively and quantitatively. The implications of this study focus on practice and research interests. For students, this study is expected to increase the level of their personal values, from less-consciousness to more-consciousness of learning identity through their involvement in this research. Furthermore, for teachers, this research enables teachers or parents to investigate 
Nurhayati et al.

their roles in adolescents' identity formation process. Also by understanding of the outcomes of this study, we expect teachers can easily identify the correlation between learner identity and level of learner awareness in the context of adolescents' identity formation.

This study was financially supported by Sukma Foundation. The School of Education, University of Tampere is also gratefully acknowledged. 


\section{BIBLIOGRAPHY}

American Psychologist Association. 2002. "Developing adolescents: A reference for professionals."

Bandura, A. 1977. "Self-efficacy: Toward a unifying theory of behavioral change." Psychological Review, 84(2), 191-215.

Bandura, A., \& Adams, N. E. 1977. "Analysis of self-efficacy theory of behavioral change." Cognitive Therapy and Research, 1-4, 287-310.

Baumeister, R. F. 1999. "Self-concept, self-esteem, and identity."

Benson, P., \& Voller, P. 1997. "Autonomy and independence in language learning." Routledge.

Berzonsky, M. D. 1990. "Self-construction over the life-span: A process perspective on identity formation." Advances in Personal Construct Psychology, 1, 155-186.

Blueprint of Sekolah Sukma Bangsa. 2005.

Bong, M., \& Skaalvik, E. M. 2003. "Academic self-concept and self-efficacy: How different are they really?" Educational Psychology Review, 15(1), 1-40.

Brockett, R. G., \& Hiemstra, R. 1991. "Self-direction in adult learning: Perspectives on theory, research, and practice." Routledge Series on Theory and Practice of Adult Education in North America. Routledge, Chapman and Hall, Inc., 29 West 35th Street, New York, NY 10001.

Brown, J. D., \& Marshall, M. A. 2001. "Self-esteem and emotion: Some thoughts about feelings." Personality and Social Psychology Bulletin, 27(5), 575-584.

Coll, C., \& Falsafi, L. 2010. "Learner identity. An educational and analytical tool La identidad de aprendiz." Una herramienta educativa y analítica. Identidad y Educación, 353, 211-233.

Côte, J. E., \& Levine, C. 1988. "The relationship between ego identity status and Erikson's notions of institutionalized moratoria, value orientation stage, and ego dominance." Journal of Youth and Adolescence, 17(1), 81-99. 
Nurhayati et al.

$\overline{\text { Department of Education and Early Childhood Development. } 2007 .}$

"Developing, monitoring and reporting on personal learning goals." State of Victoria.

Duriez, B., Luyckx, K., Soenens, B., \& Berzonsky, M. (2012). A process-content approach to adolescent identity formation: Examining longitudinal associations between identity styles and goal pursuits. Journal of Personality, 80(1), 135-161.

Erikson, E. H. 1968. "Identity, youth, and crisis.” W. W. Norton \& Company, Inc. London.

Falsafi, L. 2010. "Learner identity: A sociocultural approach to how people recognize and construct themselves as learners." (Doctorado interuniversitario de psicologia de la educacion. Doctoral thesis. Universidad de Barcelona)

Hiemstra, R. 1994. "Self-directed learning." The Sourcebook for Self-directed Learning, 9-20.

Holec, H. 1979. "Autonomy and Foreign Language Learning."

Kelly, W. A. 1965. "Educational psychology." The Bruce Publishing Company. Milwaukee.

Khor, P.Y. S. n.d. "Enhancing students' self-concept in the classroom." Teaching and Learning, 7(1), 2-8.

Kolb, A. Y. \& Kolb, D. A. 2009. "The learning way meta-cognitive aspects of experiential learning." Simulation \& Gaming 40(3), 297-327.

Lai, E. R. 2011. "Motivation: A literature review." Person Research's Report.

Lavoie, R. D. 2008. "20 tips to promote positive self-esteem in your kids." Going Bonkers 1, 16.

Maertz. n.d. "Student guide to coping with emotional crisis." University of Alberta.

Manning, M. A. 2007. "Self-concept and self-esteem in adolescents." Student Services, 2, 11-15.

Marcia, J. E. 1966. "Development and validation of ego-identity status." Journal of Personality and Social Psychology, 3(5), 551-558. 
Matthews, J. S., Banerjee, M., \& Lauermann, F. 2014. "Academic identity formation and motivation among ethnic minority adolescents: The role of the "self" between internal and external perceptions of identity." Child Development, 85(6), 2355-2373.

Ormrod, J. E. 2008. "Educational psychology: Developing learners." Upper Saddle River, NJ: Pearson/Prentice Hall.

Pajares, F. 1996. "Self-efficacy beliefs in academic settings." Review of Educational Research, 66(4), 543-578.

Rivers, S. E., Brackett, M. A., \& Salovey, P. 2008. "Measuring emotional intelligence as a mental ability in adults and children." The Sage handbook of personality theory and assessment, 2, 440-460.

Ryan, R. M., \& Deci, E. L. 2000. "Self-determination theory and the facilitation of intrinsic motivation, social development, and well-being." American Psychologist, 55(1), 68-78

Sanchez, F. J. P., \& Roda, M. D. S. 2003. "Relationships between self-concept and academic achievement in primary students." Electronic Journal of Research in Educational Psychology and Psychopedagogy, 1(1), 95-120.

Schunk, D. H. 1991. "Self-efficacy and academic motivation." Educational Psychologist, 26(3-4), 207-231.

Schwartz, S. J., Zamboanga, B. L., Luyckx, K., Meca, A., \& Ritchie, R. A. 2013. "Identity in emerging adulthood: Reviewing the field and looking forward." Emerging Adulthood, 1(2), 96-113. Slavin, R. E. 2005. "Educational psychology: Theory and practice." Allyn \& Bacon, Inc.

Song, L., \& Hill, J. R. 2007. "A conceptual model for understanding self-directed learning in online environments." Journal of Interactive Online Learning, 6(1), 27-42.

Thanasoulas, D. 2000. "What is learner autonomy and how can it be fostered." The Internet TESL Journal, 6(11), 37-48.

Whannell, R., \& Whannell, P. 2015. "Identity theory as a theoretical framework to understand attrition for university students in 
Nurhayati et al.

transition." Student Success, 6(2), 43-52.

Wright, A. 2011. "What impact does the learning environment have on self-concept?"

Yahaya, A. 2004. "Self-concepts and motivation to learn among students." Unspecified, 1-17.

Zimmerman, B. J. 2000. "Self-efficacy: An essential motive to learn." Contemporary Educational Psychology, 25(1), 82-91. 